\title{
Joanna Dziadowiec-Greganić
}

joanna.dziadowiec@gmail.com

Instytut Nauk o Kulturze i Religii

Uniwersytet Kardynała Stefana Wyszyńskiego

Fundacja ARTS

ORCID: 0000-0003-2274-7773

\section{BADANIE DZIEDZICTWA NIEMATERIALNEGO W DZIALANIU. PERSPEKTYWA KRYTYCZNA, PARTYCYPACYJNA I MEDIACYJNO-FACYLITACYJNA}

\author{
Intangible heritage research in action. Critical, \\ participatory and mediative-facilitative perspective
}

Streszczenie: Artykuł przybliża nadal stosunkowo mało popularny w Polsce - tak w antropologii, jak i w innych dyscyplinach badających w różny sposób dziedzictwo kulturowe - jego nowy paradygmat oraz ukształtowane na jego bazie interdyscyplinarne krytyczne studia nad dziedzictwem. Zakładają one m.in., że dziedzictwo jako proces jest praktyką skoncentrowaną na przeszłości, realizowaną w teraźniejszości oraz W większości z myślą o przyszłości. $Z$ natury jest niematerialne, dlatego warto postrzegać je bardziej w kategoriach czasownika niż rzeczownika. Głównym celem artykułu jest jednak - inspirowana powyższym zwrotem krytycznym - propozycja tzw. nowej metodologii w antropologicznych badaniach dziedzictwa, rozumianej nie jako alternatywa, ale uzupełnienie i dopełnienie innych podejść. Oparta na teorii heterodoksyjnej i analizach autoryzowanych dyskursów dziedzictwa, bada je według podejścia performatywnego, prakseologicznego, mediacyjno-facylitacyjnego i partycypacyjnego (w działaniu). Na bazie zaproponowanej przeze mnie synkretycznej perspektywy badawczej - na wybranych przykładach badań własnych - staram się ukazać zmieniającą się współcześnie rolę antropologa, który z „tłumacza”, interpretatora i arbitra staje się asystującym-brokerem. W konsekwencji zmienia się jednocześnie postrzeganie depozytariuszy jako jedynie badanych, edukowanych oraz aktywizowanych, a następnie monitorowanych według zaleceń i dyrektyw ogólnopolskich 
i międzynarodowych opartych przede wszystkim na polityce UNESCO i UE, które powinni wdrażać. Heterodoksyjne, partycypacyjne i mediacyjno-facylitacyjne badania dziedzictwa $\mathrm{w}$ działaniu stawiają ich $\mathrm{w}$ roli współbadaczy i równoprawnych, aktywnych graczy mających realny wpływ na współtworzenie i rozwijanie krajowego i światowego systemu ochrony dziedzictwa niematerialnego.

Słowa kluczowe: dziedzictwo niematerialne, krytyczne studia nad dziedzictwem, teoria heterodoksyjna, autoryzowany dyskurs dziedzictwa, performatywność dziedzictwa, teoria praktyk, mediacje i facylitacje dziedzictwa, partycypacyjne badania w działaniu

Abstract: The article introduces the new paradigm that is still relatively unpopular in Poland - both in anthropology and in other disciplines researching cultural heritage in different ways, and interdisciplinary critical heritage studies formed on its basis. They assume, among others, that heritage as a process is a practice centered on the past, implemented in the present and concentrated mostly on the future. It is intangible in its nature so it should be perceived more in terms of a verb than a noun. However, the main purpose of the article is a recommendation of a new methodology in anthropological heritage research inspired by the above critical turn and understood not as an alternative but as supplementing and completing other approaches. Based on heterodox theory and on authorized heritage discourses analyzes, it examines them according to performative, praxeological, mediative-facilitative, and participatory (in action) approaches. Basing on the syncretic research perspective that I suggest, which consists of the selected examples from my own research, I try to show the currently changing role of an anthropologist, who was previously perceived as a "translator", interpreter and an arbitrator, and now becomes a broker-assistant. As a result, the perception of depositaries changes. They are no longer merely researched, educated, activated, and then monitored according to national and international recommendations and directives based primarily on UNESCO and EU policies that they should implement. Heterodox, participative and mediation-facilitative heritage research puts them in the role of co-explorers, co-researchers and equal, active players who have a real impact on the co-creation and development of the national and global system of intangible heritage safeguarding. 
Badanie dziedzictwa niematerialnego w działaniu...

Key words: intangible heritage, critical heritage studies, heterodox theory, authorized heritage discourse, performativity of heritage, theory of practices, heritage mediation and facilitation, participatory research in action

[B]yć spadkobiercą nie oznacza być epigonem. Żyć w tradycji, nie oznacza ograniczać się do niej. Odziedziczyć dom, oznacza nim zarządzać, a nie przekształcać go w muzeum pozostawiając rodzicielskie sprzęty na swoich miejscach. (...) Stańcie się tymi, którymi jesteście; wówczas przyzywać będziecie przyszłość i przeszłość w żarze ogniskowej współczesności. (...) Wówczas pozyskacie rzeczywistą, „żywą" tradycję, a nie tylko rozdygotane odbicie (Jünger 2009: 9-10).

\section{Wprowadzenie}

Powyższy cytat Ernsta Jüngera przywodzi na myśl popularne wśród polskich badaczy zajmujących się w różny sposób dziedzictwem stwierdzenie Krzysztofa Pomiana, którego użył już ponad dziesięć lat temu: „nie ma dziedzictwa bez świadomości dziedzictwa” (Pomian 2010: 38). Przenosząc te konstatacje w przestrzeń antropologii kulturowej bardziej znajomy - przynajmniej biorąc pod uwagę jej wcześniejsze terenowe oblicze etnograficzne - wydaje się tu, eksponowany zresztą przez Jüngera, termin „tradycja”. Przechodząc różne koleje losu, i ona została współcześnie ochrzczona przez akademików „dobrem świadomym” (Łuniewska 2008: 93). Jako przedmiot licznych operacji, m.in. intelektualnych, kultywowana jest świadomie, a wręcz - jak twierdził Szacki - są nią nie utrwalane machinalne nawyki, lecz jedynie te elementy, których przejmowaniu towarzyszy swoista refleksja (Szacki 1971: 165-166). Dziś wielu dodaje do niej interpretację. W 1991 roku Otakar Nahodil pisał na łamach czasopisma „Lud” o tradycji jako połączeniu aktywnego procesu przekazu (tradere) z jego treścią (traditum lub tradendum), wskutek czego zawierają się w niej dwa wymiary: aktywny i dynamiczny oraz pasywny i statyczny. Rozumiana była przez niego jako subtelny, złożony, zmienny 
i w dużej mierze świadomy proces kulturowy (Nahodil 1991: 8). Domykającą klamrą jest tu koncepcja „tradycji wynalezionej” autorstwa Erica Hobsbawma i Terenca Rangera, rozumianej jako stosunkowo niedługo funkcjonujący i w większości odgórny konstrukt społeczno-kulturowy (Hobsbawm, Ranger 2008). Przyglądając się jednak współczesnym dyskursom, zarówno tym naukowym (w tym antropologicznym), jak i dyskursom instytucji kultury, wyraźnie widać, że pojęcie tradycji ustępuje dziś miejsca pojęciu dziedzictwa.

Obecnie świadomość dziedzictwa - niezależnie od tego, czy łączy się je z pojęciem tradycji, czy nie - z dyskursu naukowego przenika do niemal wszystkich dziedzin życia. Jednocześnie jednak zjawisku temu towarzyszy mnogość niepowiązanych ze sobą badań naukowych i coraz bardziej pogłębiające się rozdrobnienie pojęciowe, prowadzące do powstawania wielu osobnych oraz często osamotnionych, nieporozumiewających się ze sobą grup badawczych. Wskazuje na to pionierski tandem „heritologii”, który tworzą Gregory Ashworth i John E. Tunbridge, uchodzący dziś równolegle za najważniejszych przedstawicieli tzw. starej gwardii dziedzictwa', próbujących zwrócić uwagę na wyzwania stojące przed nowym pokoleniem badaczy śledzących różnorodne związki przeszłości z teraźniejszością (Rusek 2018: 5). Dokładniej rzecz ujmując, mam tu na myśli rozważania Tunbridge'a - jako jednego z ostatnich autorytetów i głosów wspomnianej gwardii - odwołującego się do ostatnich refleksji Gregory'ego Ashwortha zastanawiającego się nad tym, czy udało nam się zwyciężyć w krucjacie w imię dziedzictwa, czy może jednak ponieśliśmy klęskę². Według „starogwardzistów”3 badacze zajmujący się w różny sposób dziedzictwem nie tylko nie posługują się ujednoliconym słownictwem, ale również nie formułują wspólnych celów. W konsekwencji w miarę rozwoju studiów rozwija się interpretacyjna przepaść połączona $\mathrm{z}$ tym, że rozmaite koncepcje dziedzictwa bywają dodatkowo odbierane

${ }^{1} \mathrm{Tj}$. działającej przed zwrotem krytycznym (critical turn) w badaniach nad dziedzictwem.

${ }^{2}$ Tunbridge odnosi się tu do referatu Ashwortha The heritage crusade. Have we won or lost? wygłoszonego przez niego na sympozjum „The Future of Heritage” na Uniwersytecie w Brighton w październiku 2016 roku, czyli zaledwie parę tygodni przed śmiercią. Koncept „krucjaty” w imię dziedzictwa odsyła do rozważań Davida Lowenthala zawartych w znamiennej publikacji The past is a foreign country.

${ }^{3}$ Którzy jeszcze do niedawna sami byli postrzegani jako innowatorzy (przede wszystkim w środowisku konserwatorów, historyków, historyków sztuki, a także archiwistów, muzealników). 
sprzecznie z intencjami ich autorów. Tunbridge wieszczy trzy scenariusze: (1) rozmaite podmioty powiązane $\mathrm{z}$ dziedzictwem porozumieją się co do jego wspólnej definicji; (2) zaakceptują istnienie alternatywnych punktów widzenia $\mathrm{w}$ obrębie dyscypliny i uznają je za równoprawne (3) staną się jeszcze bardziej rozbieżne i rozdrobnione - wyznawcy odmiennych poglądów będą szukać sobie odpowiedniego azylu (Tunbridge 2018: 295-299).

Niniejszy tekst ma za zadanie nie tyle próbować analizować prawdopodobieństwo przybliżonych scenariuszy czy rozstrzygać rozbieżności interpretacyjne, ile skupić się na kluczowym aspekcie stojącym u podstaw rozwoju samego pojęcia jako takiego i kariery, jaką zrobiło w kręgach akademickich $\mathrm{i}$ - przede wszystkim - pozaakademickich. Mam tu na myśli zasygnalizowany na samym początku wzrost świadomości obecności różnych wymiarów przeszłości w teraźniejszości, połączony z przydawaniem owym wymiarom ważności oraz prowadzący do ukształtowania postaw i działań mających na celu ich różnie rozumianą ochronę. Dodatkowo już na wstępie pragnę podkreślić, że skoncentruję się na nowym paradygmacie dziedzictwa i wynikającej z niego koncepcji ochrony, nadal stosunkowo mało popularnym w naszym kraju - zwrocie krytycznym oraz ukształtowanej na jego bazie teorii heterodoksyjnej. Ponadto owe świadome heterodoksyjne podejścia do dziedzictwa zawężę głównie do tej jego sfery, którą UNESCO ochrzciło mianem niematerialnego dziedzictwa kulturowego (intangible cultural heritage), oraz spróbuję ulokować

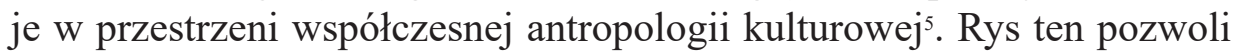
z kolei przybliżyć obrane przeze mnie ścieżki badania dziedzictwa niematerialnego (oraz wynikającą z nich zmieniającą się rolę antropologa), będące w dużej mierze interpretacją studiów krytycznych ${ }^{6}$ i następstwem perspektywy heterodoksyjnej. Swoje cele zrealizuję w oparciu o następu-

${ }^{4}$ Heritolog zaznacza, że obecnie sytuacja zdaje się zmierzać w tym właśnie kierunku.

${ }^{5}$ Mam tu na myśli głównie nurt poststrukturalny, interpretatywny, refleksyjny, symboliczny, semiotyczny, performatywny, krytyczny oraz studia kulturowe (cultural studies), ze szczególnym uwzględnieniem brytyjskich studiów kulturowych, których założenia interpretacyjne $\mathrm{w}$ wielu miejscach korespondują z podejściami popularnymi $\mathrm{w}$ różnych obszarach tak dzisiejszej antropologii, jak i socjologii.

${ }^{6} \mathrm{Tj}$. podejściem czerpiącym z ich rozwiązań, jednak nie mającym na celu wpisania się w ten ich nurt, który koncentruje się na krytykowaniu czy wręcz negacji tzw. profesjonalnych, zawodowych zinstytucjonalizowanych działań ochronnych zogniskowanych wokół międzynarodowego systemu UNESCO, którego ostre i skrajne formy określane bywają nawet anty-dziedzictwem (Winter 2013: 533). 
jące perspektywy: performatywną, prakseologiczną, mediacyjno-facylitacyjną i partycypacyjną. Poprzez zaproponowanie tych podejść postaram się ukazać, że w połączeniu (jako kompatybilna, spójna całość) mogą one otworzyć drogę do nowej metodologii antropologicznych badań dziedzictwa. Jednocześnie spróbuję odpowiedzieć na pytanie, czy wprowadzenie wypracowanej metodologii, bazującej na teorii heterodoksyjnej, może przyczynić się do zmiany postrzegania depozytariuszy jako jedynie badanych oraz do przełamania ich pasywnej pozycji w krajowym i światowym systemie ochrony dziedzictwa niematerialnego. Obecna sytuacja, mimo wyraźnych wskazań UNESCO głoszących, że nic o depozytariuszach bez nich, w rzeczywistości pozbawia ich faktycznej decyzyjności i sprawia, że nie mają oni realnego wpływu na współtworzenie i rozwijanie tego systemu.

\section{Nowy krytyczny paradygmat dziedzictwa i jego „ochrony”}

Tunbridge pisze, że wzrost świadomości dotyczącej dziedzictwa (zapoczątkowany w obrębie ruchu konserwatorskiego) przyczynił się do rozwoju wielostronnej debaty nad tym, jak powinno być ono definiowane, jakie są jego cele i do jakiego stopnia powinno ono zaistnieć w powszechnej świadomości:

Pod koniec lat 70. było już jasne - przynajmniej dla niektórych - że dziedzictwo oznacza selektywne i nakierowane na teraźniejszość wykorzystywanie zasobów z przeszłości i jako takie może służyć do uzasadniania konkretnej polityki, jednoczenia społeczeństw i generowania zysków (Tunbridge 2018: 292).

Jednak dopiero koncepcja dziedzictwa niematerialnego, nieuchwytnego (intangible), postrzeganego w kategoriach semiotycznych i prakseologicznych otworzyła drogę do jego interpretacji. Jak zaznacza Barbara Kirshenblatt-Gimblett w rozmowie z Karoliną J. Dudek oraz Sławomirem Sikorą o wymownym tytule Wytwarzanie dziedzictwa - dziedzictwo to według powszechnej wiedzy coś z przeszłości, co ma wartość, oznacza jakąś wartość dodaną. „Nazwać coś »dziedzictwem《 to nadać mu tę wartość, a także podejmować kroki, by to przekazać, zachować, bronić i chronić" (Dudek, Sikora 2016: 40). Jednocześnie jednak badaczka rozumie je jako szczególny sposób produkcji kulturowej, w którym wytwarza się coś nowego, co równocześnie odwołuje się do przeszłości (Kirshenblatt- 
-Gimblett 1998). Produkcja ta - jak twierdzi również wielu innych badaczy - działa w sferze regulacji tożsamości kulturowych i narodowych. Równocześnie dziedzictwo rozumiane jest w tym przypadku również jako dyskurs, który tej sfery dotyczy (Bendix 2009, Byrne 1991, Hall 1999, Smith 2006, Waterton 2009).

I jedno, i drugie podejście bazuje na postawach i czynnościach celowych oraz uświadomionych, skoncentrowanych na przeszłości, realizowanych jednak w teraźniejszości i w większości z myślą o przyszłości. W takim układzie dziedzictwo coraz częściej jest rozumiane jako proces, podczas którego zachodzi negocjowanie owej przeszłości, a przez to i ukształtowanej na jej bazie tożsamości (Smith 2016: 26). Owe procesualne, dyskursywne praktyki wobec przeszłości własnej - a czasem, co ciekawe, również obcej - określa się obecnie coraz częściej mianem patrymonializacji (heritization/heritagization), które tłumaczy się niekiedy także jako udziedzicznienie (Smith 2006; Harrison 2013; Bernbeck 2013; Bujdosóa, Dávidb, Tőzsérc i in. 2015; AlAnood Bin AlShaikh 2017; Kowalski 2013; Klekot 2015). Na polskim gruncie Małgorzata Zawiła zaproponowała jeszcze inny termin - dziedziczynienie (Zawiła 2019). Na pozór subtelne rozróżnienie tych terminów może stanowić klucz do zrozumienia ważnych dystynkcji między odgórnymi i - znacznie częściej - zewnętrznymi działaniami w odniesieniu do konkretnego dziedzictwa a jego wewnętrznym i oddolnym praktykowaniem. Kolejną kwestią, wynikającą po części z niniejszego rozróżnienia, jest to, czy owe procesy udziedzicznienia, stanowienia, wytwarzania i produkcji dziedzictwa są jedynie domeną ekspertów. Między innymi tego typu rozważania stały się podstawą, zdobywających obecnie coraz większą popularność w różnych częściach świata, krytycznych studiów dziedzictwa (critical heritage studies).

Krytyczny zwrot w badaniach dziedzictwa zakłada interdyscyplinarność: ,żadna szczególna dyscyplina nie powinna »posiadać« krytycznych badań nad dziedzictwem, a natura badań w tym obszarze nie powinna być umieszczona w zamkniętym polu metaforycznym" (Wells 2017). Brak umiejscowienia w obrębie jednej dyscypliny akademickiej oraz pluralistyczność perspektyw występujących w obrębie krytycznych studiów dziedzictwa powodują, że zdefiniowanie ich jest niezwykle trudne. $\mathrm{Na}$ potrzeby niniejszego artykułu pozwolę sobie zebrać tylko niektóre z tych różnorodnych perspektyw, które wskazują na nowy paradygmat tak samego dziedzictwa, jak i jego ochrony: 
- orientacja ontologiczna i epistemologiczna krytycznych studiów dziedzictwa ukształtowała się na teorii postkolonialnej, poststrukturalistycznej i postmodernistycznej;

- krytyczne studia dziedzictwa dotyczą teraźniejszości, a nie przeszłości - dziedzictwo jest praktyką konstruowaną w teraźniejszości (Emerick 2014); ,jest stale wybierane, odtwarzane i renegocjowane w teraźniejszości" (Harrison 2013: 165); to sposób, w jaki przeszłość staje się ,aktywna i żywa” w teraźniejszości (Silverman, Waterton, Watson 2017: 8);

- wartości dziedzictwa nie są wrodzone, immanentne i stałe, zatem najlepiej rozumieć je jako procesy, które podlegają ciągłym zmianom;

- autentyczność dziedzictwa jest pluralistyczna i nie jest kontrolowana przez żadną jednostkę lub grupę, definiowana jest przez wartości społeczne, kulturowe lub osobiste i może nie mieć bezpośredniego związku z jego strukturą fizyczną;

- dziedzictwo jest procesem, a nie rzeczą, i z natury jest niematerialne - to „ciągły, eksperymentalny dialog z przeszłością: »proces « zamiast »produkt«, dziedzictwo jest czasownikiem, a nie rzeczownikiem” (Emerick 2014: 190); ,jeśli dziedzictwo jest mentalnością, sposobem poznania i widzenia, wówczas całe dziedzictwo staje się w pewnym sensie »niematerialne «” (Smith 2006: 43); „całe dziedzictwo jest niematerialne i jest negocjowane $\mathrm{w}$ ramach procesów społeczno-kulturowych" (Harrison 2010a: 3);

- dziedzictwo służy do konstruowania, rekonstruowania i negocjowania szeregu tożsamości oraz wartości i znaczeń społecznych i kulturowych w teraźniejszości (Smith 2006: 3);

- dziedzictwo jest z natury dysonansowe (Tunbridge, Ashworth 1996) i tworzone jest przez ciągły proces konfliktów i negocjacji (Smith 2006: 82; Daly, Chan 2015: 492);

- krytyczne studia dziedzictwa ,zmieniają kulturę praktyk ochronnych i sposób wykorzystywania wiedzy specjalistycznej z zakresu dziedzictwa, oferując alternatywne sposoby tworzenia dziedzictwa" (Emerick 2014: 226);

- dziedzictwo jest wszędzie; wszyscy jesteśmy ekspertami dziedzictwa (Wells 2017);

Ponadto najczęściej podnoszoną kwestią jest to, że krytyczne studia dziedzictwa są reakcją na Autoryzowany/Usankcjonowany Dyskurs 
Dziedzictwa - AHD (Authorised Heritage Discourse), należący do ekspertów oraz włodarzy, dodatkowo wywodzących się z uprzywilejowanej kultury zachodniej (Smith, Shackel, Campbell 2012: 4). Laurajane Smith, będąca autorką zarówno tej koncepcji, jak i samego pojęcia, pisze wprost, że „negocjowanie znaczeń dziedzictwa jest »walką o władzę«, ponieważ dziedzictwo samo w sobie jest zasobem politycznym" (Smith 2006: 281). Logan i Wijesuriya piszą, że dziedzictwo powstaje w wyniku procesów społeczno-politycznych odzwierciedlających struktury władzy danego społeczeństwa (Logan i Wijesuriya 2015: 569). W takim ujęciu krytyczne studia dziedzictwa badają współczesne relacje między ludźmi, dziedzictwem i władzą. Co więcej, Smith twierdzi, że AHD został stworzony świadomie w celu „odsunięcia” dyskursów większości interesariuszy (Smith 2006: 106).

W konsekwencji przybliżonych tu perspektyw w obrębie krytycznych studiów dziedzictwa ukształtowała się heterodoksyjna teoria dziedzictwa, mająca stanowić przeciwwagę - a wśród skrajnych przedstawicieli tej teorii opozycję - do ortodoksyjnej teorii konserwatorskiej. Heterodoksja w dziedzictwie polega na uznaniu wielu prawd, które oparte są w większości raczej na semiotyce niż na materializmie. Ochrona jest tutaj środkiem, a nie celem samym w sobie. To sposób na utrzymanie i wzmocnienie znaczeń zarówno w danym obiekcie, jak i w praktyce dziedzictwa, znaczeń podzielanych przez daną społeczność. Sprawia to, że znaczenie dziedzictwa ulokowane jest nie w przeszłości, a w teraźniejszości (Wells 2017). Jak stwierdza Ewa Klekot, ,zadaniem antropologicznych badań nad dziedzictwem jest śledzenie praktyk, systemów wartości i motywacji różnych aktorów społecznych uwikłanych w proces stanowienia dziedzictwa" (Klekot 2016: 13). W efekcie badania dziedzictwa są badaniami procesów patrymonializacji i udziedzicznienia, dyskursów, praktyk, zjawisk oraz połączonych z nimi artefaktów i miejsc odnoszących się do przeszłości w sposób znaczący. Kierując się założeniami krytycznych studiów nad dziedzictwem chodzi, według mnie, przede wszystkim o skupienie się na perspektywie uwzględniającej społeczno-polityczną i międzykulturową złożoność i wielowymiarowość sieci, w jaką dziedzictwo jest uwikłane (Winter 2013: 533). Dodatkowo za każdym razem chodzi o tzw. konkretne dziedzictwo tj. dziedzictwo konkretnej społeczności, która nigdy nie jest jednorodna. Tym samym jej przedstawiciele wytwarzają wiele dyskursów dziedzictwa - tych autoryzowanych i tych niejako poza głównym nurtem, pobocznych. Wszystkie one z kolei są odbiciem bezpośred- 
nich praktyk dziedzictwa niematerialnego oraz działań mających na celu przede wszystkim szeroko pojętą ochronę tychże praktyk.

\section{Performatywność dziedzictwa - pomiędzy praktykami dziedzictwa a działaniami na ich rzecz}

Zawarte w członie tytułu artykułu sformułowanie „w działaniu” odnosi się do performatywnego podejścia do dziedzictwa. Bazą są tu bezpośrednio założenia performatyki, polegające m.in. na przeniesieniu zainteresowań badawczych ,z człowieka jako istoty wytwarzającej [lub jedynie odtwarzającej] na człowieka jako istotę działającą, (...) z narracji na akcję, z kontemplacji na działanie, z tego, co się stało, na to, co się staje, z komunikacji pośredniej na komunikację bezpośrednią" (Dudzik 2009: 423). Wieloznaczny, wielopoziomowy i niezwykle operatywny termin ,performans" (ang. performance) - poza popularnymi definicjami widowiskowymi - wyjaśnia się jako „wykonanie czegoś”, „wytworzenie-stworzenie czegoś". Rozumiany jest on jako aktywny pokaz, aktywna (re)prezentacja i jednocześnie aktywny przekaz zawieszony pomiędzy dromena (dzianie się, akt) a drama (akcja odgrywana), którym zawsze przyświeca jakaś intencja. Zasadniczym postulatem jest tu procesualna wizja rzeczywistości, a podstawowym mechanizmem procesualności - sprawcze, rekursywne działanie, które reprezentuje rzeczywistość społeczno-kulturową, a zarazem ją wytwarza (Schechner 1988, 2002, 2006; Hymes 1975; MacAloon 2009)7. W skrajnej postaci przedstawiciele zwrotu performatywnego uważają, że owa procesualna rzeczywistość kulturowa nie istnieje poza działaniem aktywnych-sprawczych podmiotów, które ją wytwarzają. Ponadto - co kluczowe zarówno dla heterodoksyjnych, krytycznych koncepcji dziedzictwa, jak i dla dalszych rozważań dotyczących metod jego badania w działaniu - konceptualizacja świata jako performansu każe postrzegać go nie z zewnątrz, lecz od środka - z perspektywy równoprawnych uczestników.

W rozumieniu dziedzictwa z tej perspektywy jest ono „przedstawiane”jednak nie w znaczeniu zaaranżowanej, zamkniętej, skończonej, jasno określonej i odgrywanej, na bazie zapisu, scenariusza i źródła, inscenizacji - tj. nie w sposób konstatywny, statyczny i stwierdzający, a sprawczy

${ }^{7}$ Por. koncepcja aktów performatywnych, których nie da się postrzegać w kategoriach prawdy lub fałszu Johna Langshawa Austina (Austin 1962, 1993). 
Badanie dziedzictwa niematerialnego w działaniu...

i wykonawczy: poprzez wspomniane podejście „w działaniu”, „w akcji”, „W realizacji”, „W procesie” - „dziedzictwo dziejące się”, „dziedzictwo-proces". Susie West i Marion Bowman piszą wprost o dziedzictwie jako performansie (West, Bowman 2010: 277-305). Akcent zostaje wówczas położony zdecydowanie na praktykę wykonawczą, a dokładniej praktyki oscylujące pomiędzy wytwórczością a odtwórczością, prowadzące do nieustannego stwarzania i odradzania się rzeczywistości kulturowej danej społeczności wciąż na nowo.

Jednym $\mathrm{z}$ najbardziej obrazowych rodzajów praktyk dziedzictwa niematerialnego, pozwalającym dostrzec i zrozumieć przedstawioną tu perspektywę, są widowiska kulturowe (cultural performances) ${ }^{8}$. Zawieszone pomiędzy świętem, rytuałem, obrzędem i obyczajem a zabawą, grą, teatrem i wydarzeniem (eventem) stanowią rodzaj symbolicznego wykonywania (formowania, odgrywania i przeżywania) komentarzy metaspołecznych. Zaprogramowane w czasie i przestrzeni, dokonują ześrodkowania się społeczności na aktywnym podtrzymywaniu i redefiniowaniu tradycji oraz na refleksji o społecznych więziach i komunikacji tworzących i odnawiających się wokół niej (Kolankiewicz 2005: 23). Instytucją, w której napięcie to widać ze zwielokrotnioną wręcz siłą, jest festiwal. Współcześnie, niezależnie od tego, czy ma on zasięg regionalny, ogólnokrajowy czy międzynarodowy oraz czy ma formę przeglądu czy konkursu, coraz częściej mamy w jego przypadku do czynienia z wyspecjalizowanym synkretycznym systemem strukturalno-organizacyjnym, w którym jak w soczewce widać niemal wszystkie opisane tu procesy. Jedno z najbardziej reprezentatywnych miejsc zarówno do przedstawiania, promocji, jak i kultywowania konkretnych tradycji - praktyk dziedzictwa

${ }^{8}$ Zaliczone w Konwencji UNESCO 2003 do domen: sztuki widowiskowe oraz zwyczaje, rytuały i obrzędy świąteczne. Pojęcie ,widowisko kulturowe” stało się popularne dzięki Miltonowi Singerowi, który rozumiał przez nie instytucję będącą ucieleśnieniem najważniejszych aspektów symbolicznych tradycji w danej kulturze. Według niego posiada ona treść kulturową przekazywaną przez media kulturowe oraz przez ludzi, czyli żywe przekaźniki tradycji. Dzięki temu opis sposobów, w jaki owa zawartość jest organizowana i przekazywana przy konkretnych okazjach przez media, pozwala wyszczególnić struktury tradycji, komplementarne względem jej społecznej organizacji, takie jak np. śluby, uroczystości religijne, recytacje, sztuki, tańce, koncerty. Singer stwierdził ponadto, że prawdopodobnie większość społeczeństw uważa, iż cała ich kultura zawiera się w poszczególnych widowiskach, które mogą być prezentowane zarówno na własny użytek, jak i osobom z zewnątrz (Singer 1959). 
niematerialnego ${ }^{9}$ - stanowi jeden z najbardziej spektakularnych (a często również marketingowych) przykładów udziedzicznienia - patrymonializacji. Co ważne, zarówno jeśli chodzi o wykonawców, jak i widzów-odbiorców. W żadnym bowiem festiwalu - jako rodzaju święta - nie można uczestniczyć na odległość. Zderzenie tych obu centralnych pojęć w połączeniu z opisanymi tu procesami daje jeden z najpopularniejszych modeli „ochrony” i zarządzania tą sferą: festiwale dziedzictwa niematerialnego, funkcjonujące w powszechnym dyskursie nadal jako festiwale folklorystyczne (zob. Dziadowiec 2012, 2014, 2016a, 2016b, 2016c, 2017; Dziadowiec-Greganić 2019). Innym pokrewnym przykładem koncentrującym się na (re)prezentacji praktyk, które w konwencji UNESCO określone zostały jako „umiejętności związane z rzemiosłem tradycyjnym” (traditional craftsmanship), są szeroko pojęte jarmarki i targi, które często łączy się dziś ze scenicznym wymiarem festiwalowym (zob. Dziadowiec 2017; Dziadowiec-Greganić, Dudek 2019).

Zaproponowane podejście odsyła do konstruktywistycznego rozumienia dziedzictwa opisanego powyżej, nie zatrzymującego się jednak wyłącznie na snuciu wokół niego narracji-opowieści. W tym momencie jeszcze bardziej wymownego charakteru nabiera bowiem (intencjonalny) akt udziedzicznienia - patrymonializacji - jako czynności prowadzących do postrzegania dziedzictwa jako czasownika. Jednocześnie wcale nie musi to oznaczać całkowitego zarzucenia aksjologicznego podejścia deklaratywnego zorientowanego na wartości.

Performatywne rozumienie dziedzictwa koresponduje $\mathrm{z}$ teorią praktyk Theodora Schatzkiego (Schatzki 1996, 2001, 2012) i Andreasa Reckwitza (Reckwitz 2002a, 2002b), którzy w aktywnościach społecznych poczynili wyraźne rozróżnienie na displaying - wystawianie na pokaz, modelowanie, eksponowanie, manifestowanie, a doing, tj. aktywności dziejące się, działające. Zwrot ku praktykom (practice turn, practice shift) zakłada ich konstytutywną rolę. Rozumiane są one jako strumienie ludzkiej aktywności, zorganizowane wokół wspólnej praktycznej wiedzy oraz zdolności i umiejętności jej wykorzystywania. Stanowią swego rodzaju realizację know how to do, czyli ,wiedzy, jak coś się robi”, ,wiedzy-przepisu aplikowanej w działaniach" (knowledge in action). To wiedza podzielana, której realizacja nie ogranicza się jednak do niezmiennych działań rutynowych. Według Schatzkiego podejście zorientowane na praktyki pozwala rekon-

\footnotetext{
${ }^{9}$ Często określanych zbiorczo artystycznymi: muzyka, śpiew, taniec, sceniczne opracowania obrzędów, artystyczne rękodzieło i sztuka nadal określana mianem ludowej.
} 
struować i dekonstruować zbiory znaczeń i interpretacji danej wspólnoty, które mogą być nieuchwytne dla badań koncentrujących się na wartościach czy normach kulturowych ,podzielanych” przez członków danej grupy i wyrażanych przez nich w sposób deklaratywny. Zdaniem m.in. Reckwitza teorie praktyk, podobnie jak analiza dyskursu, proponując nową ontologię, obiecują ,przekroczenie”, wyjście poza lub „ponad” dotychczasowe dychotomie, np. agency - structure; działanie - myślenie; szanse - zagrożenia; żywe - nieżywe; autentyczne - stylizowane, oraz zmianę w definiowaniu kultury. Rozumienie tej ostatniej jako wewnętrznej idei lub sieci znaczeń ustępuje miejsca analizie w kategoriach dwóch typów zewnętrznie obserwowalnych procesów. Po pierwsze - praktyk jako takich, po drugie - dyskursu, w tym również o tychże praktykach.

Takie postrzeganie i wyjaśnianie dziedzictwa lokalnego wpisuje się w jedno z trzech rozumień kultury wyróżnionych przez Zygmunta Baumana: kultury jako praxis, czyli sfery działań i praktyk społecznych jego uczestników, podczas których tworzy się sieć znaczeń (Bauman 2012) ${ }^{10}$. Kierując się założeniami teorii praktyk akcentującej wytwarzanie - „robienie" (doing), a nie wystawianie na pokaz już zrobionego (displaying), przytoczone powyżej praktyki artystyczne oraz rzemieślnicze i rękodzielnicze praktyki dziedzictwa niematerialnego odziedziczyć można właściwie jedynie w formie czasownikowej, tj. czynnego przekazu (najlepiej) międzypokoleniowego know how to do in action. Współgra to z tzw. nową teorią rzemieślnictwa Richarda Sennetta, który koncentruje się na zrozumieniu tego, ,jak" ludzie wytwarzają rzeczy, nie jedynie na przedstawianiu publiczności efektu niekiedy długiego procesu (wy)twórczego oraz tego, z jakich materiałów dana rzecz została wykonana i w jakim celu (Sennett 2008). Analogicznie do tej zasady UNESCO - uznające tradycyjne rzemieślnictwo za najbardziej materialną manifestację niematerialnego dziedzictwa kulturowego - podkreśla, że wszelkie wysiłki mające na celu ochronę tradycyjnego rzemieślnictwa powinny koncentrować się nie tyle na zachowaniu przedmiotów rzemieślniczych - bez względu na to, jak mogą być one piękne, cenne, rzadkie i ważne - ale na stworzeniu warunków, które zachęcą rzemieślników do dalszego wytwarzania rzemiosła wszelkiego rodzaju oraz do przekazywania swoich umiejętności i wiedzy innym, szczególnie w swoich własnych społecznościach ${ }^{11}$.

\footnotetext{
${ }^{10}$ Pozostałe dwa to kultura jako koncepcja i kultura jako struktura.

${ }^{11}$ Traditional Craftsmanship, https://ich.unesco.org/en/traditional-craftsmanship-00057
} 
Wraz z Agnieszką Dudek rozważałyśmy ten temat na przykładzie profesji rzemieślniczych i rękodzielniczych w małopolskiej gminie Wiśniowa ${ }^{12}$. Zarówno artystyczne, jak i użytkowe praktyki (wy)twórcze - co ważne, uchodzące wśród mieszkańców Wiśniowej za tradycyjne i traktowane przez nich jako lokalne dziedzictwo - zogniskowałyśmy wokół klucza handmade in Wiśniowa oraz handlu będącego sposobem dystrybucji owoców tych pierwszych, m.in. w specjalnie do tego zaaranżowanej przestrzeni miejscowego targu - jarmarku (zob. Dziadowiec-Greganić, Dudek 2019).

Prakseologiczne podejście do dziedzictwa reprezentuje Rodney Harrison. Czyni on rozróżnienie na odgórne, oficjalne, instytucjonalne oraz oddolne, nieoficjalne praktyki dziedzictwa (practices of heritage). Według niego te pierwsze oznaczają procesy identyfikacji, zarządzania i konserwacji oraz ochrony, które osadzone są w ustawodawstwie i władzy. Tymczasem te drugie mogą nie zostać uznane przez rządy lub nie są wymieniane w oficjalnych rejestrach i listach dziedzictwa, są jednak uważane przez społeczności i wspólnoty za ważne i kulturowo znaczące w sposób, w jaki konstytuują się i działają w teraźniejszości, czerpiąc z aspektów przeszłości (Harrison 2010b: 240). Harrison bazuje tutaj na koncepcji dziedzictwa oddolnego (heritage from below) Robertsona (Robertson 2008). Ponadto zwraca on uwagę na to, że dziedzictwo rozumiane jako praktyka (a dokładniej zbiór praktyk) może przybierać dodatkowo formę akcji społecznej czy też działania społecznego (social action), które może stać się sposobem na przetarcie się praktyk nieoficjalnych i nieuprzywilejowanych przez oficjalne procesy dziedzictwa. Na konkretnych przykładach grup mniejszościowych przybliża on takie formy ich dziedzictwa jako działania społecznego, które ustalane są na poziomie oddolnym i działają $\mathrm{w}$ bezpośredniej opozycji do praktyk zarządzania dziedzictwem prowadzonych przez państwo. Niemniej jednak zaproponowany przez niego układ nie musi polegać jedynie na opozycji. W konsekwencji oddolne, nieusankcjonowane praktyki dziedzictwa, przybierające w odpowiednich kontekstach formy akcji i działań społecznych, mogą być nie tyle przeciwwagą, co równowagą dla praktyk oficjalnych -

\footnotetext{
${ }^{12}$ Należy dodać, że ważnym aspektem projektu były międzykulturowe wymiary wiśniowskiego dziedzictwa, gdzie w przypadku tradycyjnych profesji rzemieślniczych do II wojny światowej dominującą rolę odgrywało dawne rzemieślnictwo żydowskie. Wywiady z mieszkańcami gminy ukazały, że temat ten jest nadal silnie obecny w pamięci społeczno-kulturowej.
} 
autoryzowanych. Wreszcie sam Harrison twierdzi, że „nie tylko nieoficjalne praktyki dziedzictwa mogą być postrzegane jako rodzaj dziejącej się "pracy« społecznej (doing social 'work') lub społecznej interwencji czy sprawczości (social agency)" (Harrison 2010b: 260). Analizuje on bowiem również sposoby, wedle których jednostki i społeczności mogą wykorzystywać oficjalne praktyki dziedzictwa do kwestionowania lub interwencji w główne (mainstreamowe) systemy dziedzictwa oraz związane z nimi konwencjonalne praktyki dziedzictwa, a poprzez to zmieniać sposoby myślenia danych społeczności tak o sobie samych, jak i o swoim własnym dziedzictwie ${ }^{13}$. W konsekwencji może dojść do przełamania dominujących dyskursów dziedzictwa kształtujących je na swój własny obraz, dyskursów tak otwarcie kwestionowanych przez Smith. Harrison podkreśla, że dziedzictwo przyjmuje formę akcji społecznej, gdy jednostki i grupy próbują obalić ów stan dominacji i tworzą tzw. dziedzictwa kontrkulturowe (counter-cultural heritages). Niemniej jednak działania takie nie muszą przybierać skrajnej formy aktywizmu. Mogą to być bowiem dziedzictwa nie tyle przeciw, co obok zinstytucjonalizowanych dominujących form publicznych lub poza nimi. Natomiast takie nieoficjalne wyzwania dla oficjalnych praktyk związanych z dziedzictwem oraz alternatywne wartości i dyskursy, które stanowią ich podstawę, niewątpliwie mogą być niezwykle płodne, silne i skuteczne oraz mieć potencjał, aby oficjalne definicje dziedzictwa uczynić bardziej inkluzywnymi. To z ko-

13 Tego typu sytuacja miała miejsce w pogranicznej gminie Wiśniowa, zarówno podczas realizacji wspomnianego wyżej projektu, jak i w czasie wcześniejszych badań prowadzonych przez dialektologów z Uniwersytetu Jagiellońskiego. Gmina należąca do powiatu myślenickiego, zlokalizowana na pograniczu trzech regionów zamieszkałych przez różne grupy etnograficzne (górali: Zagórzan i Kliszczaków w części południowej za pasmem Lubomira i Łysiny, Lachów Limanowskich i Lachów Szczyrzyckich w części wschodniej i południowo-wschodniej oraz Krakowiaków Zachodnich w części zachodniej i północnej, stanowiącej największy obszar) została przez etnografów zaszeregowana jako „teren przejściowy”, który do dziś nie doczekał się osobnych, bardziej szczegółowych opracowań. Przedstawiciele lokalnej społeczności uznali ów termin za niefortunny. Stał się on ,punktem zapalnym” dyskusji o ich tożsamości (a co za tym idzie - o ich dziedzictwie: krakowskim? góralskim? lachowskim?). „Teren przejściowy, czyli jaki?" - takie pytanie padało wielokrotnie w trakcie spotkań z mieszkańcami gminy. Pojawiły się w tym kontekście stwierdzenia brzmiące nawet humorystycznie: „Kto nas przeszedł? Z której i na którą stronę?”. Projekt „Wiśniowski Jarmark...” stał się swego rodzaju odpowiedzią na funkcjonujące, pejoratywne - w odczuciu niektórych mieszkańców - określenie ich terenu oraz długotrwałe pomijanie gminy przez badaczy. Działania mieszkańców są doskonałym przykładem współczesnego aktywnego, refleksyjnego i sprawczego podejścia do dziedzictwa kulturowego. 
lei może doprowadzić do sytuacji, w której poszczególne społeczeństwa (a nie tylko pomniejsze wspólnoty stanowiące ich część) zmienią postrzeganie swojej przeszłości, a co za tym idzie - również swojej teraźniejszości i przyszłości.

\section{Mediatorzy, facylitatorzy i brokerzy kulturowi - antropolodzy jako pośrednicy $w$ sferze dyskursów i praktyk dziedzictwa niematerialnego}

W książce o wymownym tytule Brokers, Facilitators and Mediation. Critical Success (F)Actors for the Safeguarding of Intangible Cultural Heritage, będącej pokłosiem międzynarodowej konferencji ${ }^{14}$ zorganizowanej w Brukseli z okazji 10. rocznicy Konwencji UNESCO 2003, autorzy przedstawiają koncepcję kulturowego pośrednictwa (cultural brokerage), umieszczając ją jednocześnie w nowym paradygmacie ochrony dziedzictwa zapoczątkowanym przez Konwencję 2003 (Jackobs, Neyrinck, van der Zeijden 2014). Główna hipoteza dotyczy istotności roli mediatorów, pośredników kulturowych lub facylitatorów w sprawianiu, aby plany i programy ochrony oraz inne partycypacyjne procesy w obrębie dziedzictwa działały i odnosiły sukces. Charakteryzując brokerów poprzez wskazanie umiejętności, które powinni posiadać, opisują ich m.in. jako „tłumaczy” (translators) potrafiących znajdować wspólną płaszczyznę pomiędzy dyskursami profesjonalnymi, metodami i terminologią „ochrony” lub wprost „niematerialnego dziedzictwa kulturowego”, jako w dalszym ciągu stosunkowo nowego terminu i wiążącego się z nim konceptu. Dotyczy to także wspólnej płaszczyzny na gruncie lokalnych praktyk i procesów dziedzictwa zachodzących w danych wspólnotach. Zastanawiają się ponadto, czy słowa kluczowe, takie jak ,,pośrednictwo kulturowe” lub „mediacja”, odpowiednio opisują tych kluczowych - według nich - aktorów/,czynników” ((f)actors) sukcesu wdrażania programów i systemów ochronnych oraz czy procesy te są ograniczone do świata organizacji pozarządowych, czy też stanowią wyzwanie również dla innego typu podmiotów (Jackobs, Neyrinck, van der Zeijden 2014: 251).

${ }^{14}$ Konferencja "ICH brokers, facilitators, mediators and intermediaries. Critical Success (F)Actors for the Safeguarding of Intangible Cultural Heritage" zorganizowana została pod auspicjami Flamandzkiej komisji UNESCO przez FARO, tapis plein and the Vrije Universiteit Brussel/BREL, we współpracy z Holenderskim Centrum Dziedzictwa Niematerialnego (Nederlands Centrum voor Volkscultuur en Immaterieel Erfgoed) oraz ICH NGO Forum. 
Badanie dziedzictwa niematerialnego w działaniu...

Celem, na który otwarcie wskazują autorzy, jest doprowadzenie do tego, aby „kulturowe pośrednictwo” zostało oficjalnie wprowadzone do jednej lub kilku dyrektyw operacyjnych UNESCO.

Pojęcie mediacji wywodzi się od łac. mediatio i mediare - „być w środku”, ,pośredniczyć” oraz od medius - „środkowy”, „bezstronny”. Według definicji to dobrowolny i najczęściej poufny proces dochodzenia przez strony do rozwiązania problemu (najczęściej sporu/konfliktu), prowadzony w obecności osoby trzeciej cieszącej się ich zaufaniem - mediatora. Jako osoba z założenia neutralna pomaga on stronom we wzajemnej komunikacji, w określeniu interesów i kwestii do dyskusji oraz dojściu do wspólnie akceptowalnego konsensusu (Kopaliński 1970: 475). Proces mediacji odbywa się na płaszczyźnie wspomnianych interesów i potrzeb, a nie stanowisk. Ma na celu stworzenie stronom warunków umożliwiających osiągnięcie dobrowolnego porozumienia, a nie narzucenie im jakiejś autorytatywnej propozycji (np. eksperckiej). Dzięki temu możliwe jest skoncentrowanie na problemie, a nie na osobie/osobach, pozwalające wypracować rozwiązania zadowalające wszystkie strony (win-win).

Często podkreśla się, że mediator jest osobą odpowiedzialną bardziej za sam proces mediacji niż za treść, która jest jej przedmiotem. W takim przypadku mamy do czynienia z mediacją klasyczną, rodzajem facylitacji, w której mediator nie wychodzi poza rolę pomocnika w dialogu stron mediacji. Nie narzuca swoich idei i koncepcji. Nieco inną - i według niektórych teoretyków i praktyków kwestionowaną - formą jest mediacja ewaluatywna, w której mediator może sugerować pewne rozwiązania (Gmurzyńska 2009: 111-112). W przypadku dziedzictwa niematerialnego mechanizm mediacji może stanowić punkt wyjścia do podjęcia faktycznego, realnego i aktywnego dialogu pomiędzy różnymi interesariuszami danych praktyk dziedzictwa niematerialnego, tak w obrębie samej społeczności, w której one funkcjonują (bezpośredni depozytariusze, instytucje i organizacje lokalne/regionalne, przedsiębiorcy, samorządy itd.), jak i szerzej, tj. pomiędzy tą społecznością a odpowiednio instytucjami, organizacjami i władzami wyższego szczebla - ogólnopolskiego, narodowego, a w następnej kolejności międzynarodowego, na którym siłą rzeczy najistotniejszym graczem jest UNESCO ${ }^{15}$. Ten ostatni opisują na różnych przykładach autorzy wspomnianej pozycji. Sami jednak do scharakteryzowania niniejszych procesów używają dość niejednorodnej nomenklatu-

${ }^{15}$ Oczywiście trzymając się konwencji i systemu, które tego rodzaju praktykom dziedzictwa stworzyło. 
ry, która nie do końca może być stosowana wymiennie. Mam tu na myśli m.in. pojęcie facylitacji ${ }^{16}$. W przeciwieństwie do mediacji, które skupiających się na rozwiązaniu problemu, który przybiera formę konfliktu, facylitacja jest procesem mającym na celu wzmocnienie zaangażowania stron i doprowadzenie ich do wspólnie wypracowanego rezultatu. Polega na wspieraniu i rozwoju w różnych aspektach osób/grup/podmiotów biorących $\mathrm{w}$ niej udział oraz na ułatwianiu im procesu organizacyjnego prowadzącego do wykonania wspólnie (przy wykorzystaniu potencjału wszystkich członków) określonego zadania wraz ze zdefiniowanym celem lub celami do osiągnięcia. Zadaniem facylitatora jest czynny udział w udrażnianiu tego procesu. Celem takiego wsparcia jest pobudzenie aktywności i świadomego włączania się członków grupy w proces realizacji postawionego zadania w sposób holistyczny, czyli z całościowym zaangażowaniem się w działania grupy w aspekcie fizycznym, emocjonalnym oraz intelektualnym. Ponadto podstawą prowadzenia skutecznej facylitacji jest równe prawo każdego do działania i wypowiedzi, pełne zaangażowanie, poszukiwanie porozumienia i docenianie różnorodności, która pojawia się w czasie pracy grupy (Mann, Marszewska 2018).

Według Jackobsa, Neyrincka i van der Zeijdena aktywność mediacyjno-facylitacyjna, nazywana przez nich zbiorczo wspomnianym „kulturowym pośrednictwem", ma na celu budowanie konsensusu w obrębie systemu ochrony dziedzictwa niematerialnego oraz ma stanowić podstawę dla realnego współtworzenia tego systemu przez różne strony (w tym przez samych depozytariuszy) oraz „współrządzenia” (co-governance) nim. Ponadto twierdzą oni, że tego typu podejście sprawia, iż procesy ochrony stają się bardziej zrównoważone. W konsekwencji ów zewnętrzny pośrednik (broker), balansując na pewnej dynamicznej płaszczyźnie kontinuum ,pomiędzy”, tj. przyjmując, w zależności od sytuacji, rolę negocjatora, facylitatora i mediatora, może działać jako tzw. otwieracz oczu (an eye-opener) zachęcający do interpretacji i dalszego rozwoju wspomnianego systemu ochrony (Jackobs, Neyrinck, van der Zeijden 2014: 253-255). Autorzy twierdzą nawet, że może to być punkt wyjścia do faktycznego, a nie pozornego przełamania Autoryzowanego Dyskursu Dziedzictwa, na którego pułapki, również w obszarze Konwencji UNESCO 2003, wskazywała Laurane Smith (Smith 2013).

Procesy mediacyjno-facylitacyjne mogą stanowić subtelną alternatywę dla często jednowymiarowych konsultacji społecznych przede wszystkim

${ }^{16}$ Fr. facile - 'łatwy'. 
z uwagi na to, że zmieniają, czy wręcz odwracają one układ stron. Celem konsultacji, zaaranżowanych najczęściej odgórnie/instytucjonalnie, jest - w lekkim uproszczeniu - zasięgnięcie wśród członków danej społeczności opinii dotyczącej jakiejś zdefiniowanej już wcześniej kwestii lub wprost opracowanego już zarysu projektu, który w jakiś sposób tej społeczności dotyczy. Tymczasem mediacja i facylitacja zdecydowanie w większym stopniu koncentrują się na działaniach oddolnych, odśrodkowych, mających na celu zaktywizowanie samej społeczności, która samodzielnie zdefiniuje i spróbuje rozwiązać dany problem - w naszym przypadku mieszczący się w obrębie praktyk jej dziedzictwa niematerialnego - czy też wypracuje założenia oraz zrealizuje projekt mający na celu szeroko pojętą ochronę i promocję danej praktyki. Tym samym procesy mediacyjne $\mathrm{i}$ facylitacyjne realizowane przede wszystkim, a na pewno w pierwszej kolejności, na poziomie lokalnym są ciekawym rodzajem akcji społecznych na rzecz własnego dziedzictwa (social heritage action) w rozumieniu Harrisona. Mogą stanowić bowiem podłoże dla kolejnych działań w danym regionie i szerzej, poza nim, pomagających przełamać dominujące dyskursy danego dziedzictwa, otwierając drogę zarówno do zaistnienia Harrisonowskich praktyk nieoficjalnych, jak i do bardziej indywidualnych aktów ich udziedzicznienia oraz bardziej uświadomionej ich interpretacji i aplikacji we własnym życiu. W zarysowanym tu układzie profesjonalny badacz - w tym wypadku antropolog - przybrać może rolę symetrycznego pośrednika, pomocnika i animatora, nie zaś nadrzędnego eksperta-menadżera, który dyktuje warunki projektu tak badań dziedzictwa, jak i jego ochrony.

\section{Krytyczne, partycypacyjne badania dziedzictwa niematerialnego w dzialaniu}

Popularne dziś hasło „dziedzictwo w działaniu” ${ }^{17}$ podkreśla opisane wcześniej podejście performatywne oraz prakseologiczne i łączy je bez-

${ }^{17}$ Por. np. program Komisji Europejskiej Creative Europe „Cultural Heritage in Action", mający na celu zaktywizowanie miast i regionów do wzmocnienia ich polityk i inicjatyw w zakresie dziedzictwa kulturowego oraz do opracowania innowacyjnych rozwiązań na rzecz ochrony zasobów dziedzictwa kulturowego. Tworzony w konsorcjum, określany jest programem partnerskiego uczenia się i stanowi swego rodzaju kontynuację działań Europejskiego Roku Dziedzictwa Kulturowego 2018 (https://ec.europa.eu/culture/news/european-commission-launches-cultural-heritage-in-action-programme_en). 
pośrednio z perspektywą heterodoksyjną. Ponadto w zestawieniu z powyższą mediacyjno-facylitacyjną rolą - czy też bardziej postawą - jaką mogą przybierać nie tylko pracownicy instytucji i organizacji kultury (urzędnicy, administratorzy, menadżerowie, animatorzy, edukatorzy itd.), ale także badacze-antropolodzy (oraz reprezentanci innych dyscyplin), W następnym etapie otwierać może drogę do nieco innej formy prowadzenia samych badań nad dziedzictwem. W lekkim uproszczeniu, to już nie eksperci różnych maści badający społeczności lokalne, regionalne, etniczne, narodowe i ich dziedzictwo: praktyki, wytwory, artefakty itd. (dokumentacja, analiza i interpretacja, czasem - co jednak w przypad$\mathrm{ku}$ antropologii jest dość rzadkie - połączona wprost z ewaluacją). To aktywne, dosłownie dziejące się badania w terenie, będące następstwem (choć niekoniecznie) wstępnych mediacji i negocjacji różnych stron (zewnętrznych i wewnętrznych). Nie tyle specjalistyczne „badania kogoś lub czegoś” w obszarze danego dziedzictwa, co „badania wraz”, tzw. współbadania, prowadzone wspólnie przez dziedziców-depozytariuszy i brokerów-mediatorów. Taki układ odsyła niemal bezpośrednio do metody badań w działaniu (action research), a dokładniej do występujących $\mathrm{w}$ ich obrębie partycypacyjnych badań $\mathrm{w}$ działaniu (participatory action research).

Badania $\mathrm{w}$ działaniu ${ }^{18}$ jako rodzaj podejścia badawczego pojawiającego się w różnych dyscyplinach (m.in. socjologia, antropologia, pedagogika, psychologia) związane są z nowymi epistemologiami dotyczącymi praktyki społeczno-kulturowej. Odnoszą się do refleksyjnego działania jednostek i grup w świecie, mając świadomość, że jest to świat skonstruowany. Niemniej jednak najważniejszym elementem jest tu uznanie najwyższej kompetencji członków danej społeczności do rozumienia jej prawideł. Przedstawiciele tego nurtu starają się przede wszystkim zrozumieć osoby w danej organizacji lub środowisku, a nie narzucać im swoje poglądy. W przypadku działalności społecznej i kulturalnej sprowadza się to do pomagania społecznościom $\mathrm{w}$ radzeniu sobie z problemami definiowanymi tak, jak sama społeczność je postrzega, zamiast klasycznego decydowania, co jest problemem, i wymyślania rozwiązań za nią (Chrostowski,

${ }^{18}$ Termin stworzony w 1944 roku przez Kurta Lewina, użyty po raz pierwszy w pracy z 1946 roku zatytułowanej Action Research and Minority Problems, w której określił je jako badania porównawcze dotyczące warunków i skutków różnych form działalności społecznej i badań prowadzących do akcji społecznej wykorzystującej spiralę kroków, z których każdy składa się z kręgu planowania, działania i ustalania faktów o rezultacie danej akcji (Lewin, 1946: 34-46). 
Badanie dziedzictwa niematerialnego w działaniu...

Jemielniak 2011). W pewnych wymiarach widać tu punkty styczne z opisanym powyżej procesem mediacji i facylitacji. W przypadku działalności naukowej natomiast ma to swoje odzwierciedlenie w uznaniu wyższej kompetencji badanej zbiorowości do definiowania, co jest dla niej ważne. Niezależnie od tego, czy weźmiemy pod uwagę zarysowane krytyczne, konstruktywistyczne i heterodoksyjne podejście do dziedzictwa, czy też jedynie postulowane założenia dotyczące dziedzictwa niematerialnego przyświecające UNESCO, właśnie tego typu rozumowanie wysuwa się na plan pierwszy. Dziedzictwem jest to, co jest ważne dla danej społeczności, co jej przedstawiciele uważają za ważne i warte zachowania, kultywowania i przekazywania następnym pokoleniom. Nawet jeśli, biorąc pod uwagę wytyczne operacyjne Konwencji UNESCO 2003, dana praktyka musi zostać udokumentowana i przedstawiona (najpierw na poziomie krajowym, co potem może jej otworzyć drogę do list światowych) w sposób ustandaryzowany, odpowiadający wspomnianym wytycznym, to sam jej wybór i interpretacja należy do społeczności. W przeciwieństwie do eksperckiej, ortodoksyjnej doktryny konserwatorskiej oraz wytycznych Konwencji UNESCO 1972, w tym przypadku to dana społeczność jako depozytariusz jest filtrem-decydentem działań na rzecz tych praktyk ${ }^{19}$. Tym samym również badania owych praktyk dziedzictwa prowadzone są wówczas w oparciu o czynną i partnerską relację badawczą, nie tyle badacza z badanymi, co badacza zawodowego, częściej zewnętrznego z depozytariuszami będącymi tzw. badaczami wewnętrznymi, częściej amatorskimi.

Magdalena Dudkiewicz twierdzi, że w „badaniach aktywizujących” zawarta jest wewnętrzna sprzeczność. Polega ona na tym, że:

(...) słowo „badania” odnosi się do zastanej rzeczywistości - badanie dotyczy albo teraźniejszości, gdy poszukujemy odpowiedzi na pytanie ,,jak jest?”, albo przeszłości, gdy pytamy ,jak było?”. W drugim przypadku sprawa jest jasna - nie mamy żadnego wpływu na badaną rzeczywistość, w pierwszym, co do zasady, nie powinniśmy tego wpływu wywierać. Tymczasem przymiotnik ,,aktywizujący” w oczywisty sposób wskazuje na podjęte działanie, którego skutki odnoszą się do przyszłości: dziś aktywizujemy, by jutro ktoś był aktywny, czyli inicjujemy zmianę. Zmianę przedmiotu badania (Dudkiewicz 2011: 4).

${ }^{19}$ Oczywiście na początku drogi prowadzącej do udziedzicznienia danej praktyki $\mathrm{w}$ formie oficjalnej, zinstytucjonalizowanej - usankcjonowanej. 
W momencie, gdy przedmiotem badania-działania jest dziedzictwo dodatkowo niematerialne, rozumiane jako czasownik ( $\mathrm{tj}$. samo jest ono aktywnością kulturową będącą spuścizną z przeszłości) - podejście to nabiera nowego wymiaru. Mamy bowiem do czynienia z tzw. sytuacją czasowo zmultiplikowaną. Pytania ,jak było?” i ,jak jest?” przeplatają się ze sobą, co więcej, są ze sobą wręcz nierozerwalnie połączone. Ponadto łączą się one również z przyszłością - działania te, nawet jeśli nie bezpośrednio, w większości czynione są m.in. po to, by przedmiot badań miał swoją kontynuację w przyszłości. Taka forma badania-działania, prowadzona wspólnie ze społecznością lokalną, w połączeniu z podejściem zawartym w teorii praktyk - kulturowym know how to do - może okazać się katalizatorem aktywności, zaangażowania i odpowiedzialności, stwarzającym podwaliny do powstania i rozbudowywania trwałych mechanizmów partycypacyjnych, których przedmiotem będzie aktywna, świadoma i refleksyjna ochrona swojego dziedzictwa (jako działanie na jego rzecz) bazująca nie na aksjologii i deklaracji, a na praktyce, a dokładniej na konkretnych praktykach tego dziedzictwa.

Zarysowana tu charakterystyka zdradza analogie $\mathrm{z}$ antropologią zaangażowaną, która - jak pisze Hana Cervinkova - stara się przekroczyć granicę „neutralnej”, etnograficznej obserwacji i otwarcie podejmować etyczne wyzwania związane z zaangażowaniem się na rzecz ludzi (Cervinkova 2011: 9). Niemniej jednak w zaproponowanym przeze mnie podejściu badawczym w centrum rozważań znajdują się działający-badający depozytariusze, nie zaś zaangażowani społecznie antropolodzy oraz wynikające $\mathrm{z}$ tego zaangażowania kwestie etyczne. Krytyczne badania dziedzictwa $\mathrm{w}$ działaniu polegają na łączeniu przemyśleń i działań, teorii i praktyki, poprzez współpracę z innymi. To przedsięwzięcie oparte na praxis (od refleksji, przez krytykę, do działania), pomagające wspierać rozwój tak jednostek, grup, jak i całych społeczności poprzez bazowanie na ich własnym dziedzictwie. Jako narzędzie przełamywania dominującego Autoryzowanego Dyskursu Dziedzictwa mogą prowadzić do społecznej emancypacji grup, które w obrębie danych społeczności dziedzictwa są defaworyzowane (np. mniejszościowych). Jednocześnie - w przeciwieństwie do tzw. klasycznych, zaangażowanych społecznych badań w działaniu - nie muszą służyć - i zazwyczaj z założenia nie służą - jedynie osiąganiu praktycznych rozwiązań palących problemów owych społeczności. Reasumując, w proponowanym podejściu profesjonalny badacz zajmuje pozycję wspomnianego mediatora-brokera-facylitatora 
Badanie dziedzictwa niematerialnego w działaniu...

lub jedynie „wynajętego" przez społeczność posiadającego wiedzę zawodowca, nie zaś z własnej inicjatywy przybyłego aktywisty pragnącego dokonywać zmian społecznych dla dobra tejże społeczności (por. Mosse, Lewis 2006).

W scharakteryzowanym tu duchu prowadzone były wspomniane powyżej badania praktyk rzemieślniczych i rękodzielniczych w Gminie Wiśniowa ${ }^{20}$. Należy podkreślić, że projekt zainicjowany został oddolnie, tj. przez przedstawicieli lokalnej społeczności, którzy dosłownie zgłosili się do mnie, abym ,pomogła im zrobić coś z ich dziedzictwem”, a rozpoczął się od zorganizowania w miejscowym Gminnym Ośrodku Kultury i Sportu tzw. okrągłego stołu, podczas którego wspólnie zadecydowano, co będzie głównym tematem projektu. Analogicznie wszystkie kolejne jego etapy - począwszy od poszukiwania środków, napisania wniosku o dofinansowanie ${ }^{21}$, stworzenia zespołu projektowego, pozyskania partnerów, patronów aż po jego realizację - prowadzone były wspólnie z zaangażowanymi mieszkańcami. Działania na rzecz dziedzictwa prowadzone $\mathrm{w}$ ten sposób dają podstawę do traktowania ich jako odpowiedzi na realną, a nie kreowaną potrzebę mieszkańców tego regionu, świadomych potencjału, wykorzystania i interpretacji własnego dziedzictwa kulturowego. Podobny rezultat można dostrzec w zdobywającej coraz większą popularność sieci polskich i polonijnych tematycznych Archiwów

${ }^{20}$ Badania, których wyniki i efekty przedstawione zostały w publikacji Handmade in Wiśniowa. O najbardziej materialnym z niematerialnych aspektów dziedzictwa kulturowego w pogranicznej gminie Wiśniowa, w filmowym dokumencie etnograficznym o tym samym tytule (zob. https://www.youtube.com/watch?v=_okbMeQ7HKQ\&feature=emb_title) oraz na interaktywnej stronie internetowej stanowiącej zalążek wiśniowskiego lokalnego archiwum społecznego (zob. http://wisniowskijarmark.gokis-wisniowa.pl/), były częścią większego projektu badawczo-animacyjnego „Wiśniowski Jarmark Rzemiosł i Zawodów Tradycyjnych - lokalna tradycja w działaniu”. Poza szeregiem działań projektowych (spotkań ze społecznością, tematycznych debat praktyków i teoretyków, konferencji, warsztatów, wystaw, promocji i innych) niezwykle istotnym elementem był wieńczący projekt jarmark, który w zamierzeniu bazował na wspomnianych dawnych cyklicznych jarmarkach i targach wiśniowskich (odbywających się na tym terenie od ok. XVII wieku). Współtworzony był w różnym wymiarze i charakterze przez mieszkańców, a przede wszystkim przez zidentyfikowanych w trakcie projektu przedstawicieli tradycyjnych profesji: rzemieślników, przetwórców, rękodzielników, (wy)twórców, artystów.

${ }^{21}$ Do programu „Dziedzictwo kulturowe”, priorytet „Kultura ludowa i tradycyjna” Ministerstwa Kultury i Dziedzictwa Narodowego. 
Społecznych (tzw. AS-ów)22 skupionych wokół nowo powstałej instytucji kultury Centrum Archiwistyki Społecznej (CAS) ${ }^{23}$. Została ona utworzona centralnie, jednak w celu zrealizowania rosnącej oddolnej potrzeby społecznej wyrosłej obok profesjonalnej archiwistyki państwowej. Czyni to m.in. poprzez bezpłatne udostępnianie lokalnym społecznościom (co ważne, zarówno zorganizowanym, jak i niesformalizowanym) platformy do samodzielnej archiwizacji ich zasobów dziedzictwa ${ }^{24}$ oraz udzielanie wsparcia merytorycznego i metodycznego w zakresie archiwizacji i digitalizacji. Na koniec chcę jeszcze krótko wskazać na wieloletnie badania prowadzone w ramach „Nowej Akcji Zbierania Folkloru” Małopolskiego Centrum Kultury „Sokół” ${ }^{25}$. Badania terenowe realizowane są według jasno określonych, ustandaryzowanych kwestionariuszy wywiadu ${ }^{26}$, przygotowanych przez ekspertów należących do różnych dziedzin ${ }^{27}$. Pro-

${ }^{22}$ Archiwa społeczne powstają w efekcie celowej, oddolnej działalności obywatelskiej i tworzone są siłami lokalnej społeczności. Ich główną misją jest aktywne działanie na rzecz ochrony dziedzictwa kulturowego, a celem - pozyskiwanie, zabezpieczanie, przechowywanie, opracowanie i udostępnianie materiałów (dokumentowych, ikonograficznych, audiowizualnych) wchodzących w skład niepaństwowego zasobu archiwalnego. AS-y rodzą się oddolnie, m.in. po to, aby dokumentować te aspekty historii i dziedzictwa, które wykraczają poza zakres zainteresowań archiwów państwowych, m.in. tradycje wspólnot regionalnych, historię lokalną, losy tzw. zwykłych ludzi, historię organizacji pozarządowych czy historię niezależnego życia artystycznego (Archiwa Społeczne. Definicja https://archiwa.org/definicja).

${ }^{23}$ Powołana przez Fundację Ośrodka KARTA oraz Ministra Kultury i Dziedzictwa Narodowego. Misją CAS jest wspieranie archiwów społecznych w zabezpieczaniu i upowszechnianiu zbiorów, rozwijanie sieci ich współpracy i popularyzacja idei archiwistyki społecznej (https://archiwa.org/content/dzia\%C5\%82alno\%C5\%9B\%C4\%87).

${ }^{24}$ Otwarty System Archiwizacji (OSA).

${ }^{25}$ Projekt, obejmujący zadania badawczo-dokumentacyjne w zakresie ochrony, zachowania i udostępniania dziedzictwa kultury tradycyjnej Małopolski, jest częścią większego przedsięwzięcia „Małopolska Źródłem Tradycji” sfinansowanego z Regionalnego Programu Operacyjnego Województwa Małopolskiego na lata 2014-2020. W ramach NAZF planuje się przeprowadzenie ok. 1000 wywiadów w terenie (http://mcksokol.pl/ malopolska-zrodlem-tradycji).

${ }^{26}$ Obejmują one kwestionariusz do badań dialektologicznych, badań nad tradycjami muzycznymi, badań nad tańcami tradycyjnymi, badań obrzędów i zwyczajów dorocznych, badań rodzinnych, badań grupowej tożsamości, kulturowej identyfikacji i społecznych dystansów oraz badań dziedzictwa mniejszości i międzykulturowych aspektów dziedzictwa Małopolski. W projekcie jestem odpowiedzialna za przygotowanie narzędzi badawczych oraz analizę badań z dwóch ostatnich zakresów.

27 Etnografia, muzealnictwo, językoznawstwo, etnomuzykologia, etnochoreologia, antropologia kultury, heritologia. 
jekt interesujący jest jednak z tego względu, że w większości badaczami (a dokładniej zbieraczami) są zrekrutowani w otwartym naborze mieszkańcy różnych części Małopolski. Przeprowadzają oni badania w swoich własnych miejscowościach, gminach i powiatach. To po części amatorzy, pasjonaci, lokalni liderzy. Dodatkowo w wielu przypadkach są to osoby zaangażowane $\mathrm{w}$ regionalny ruch kulturalny, artystyczny czy też wprost folklorystyczny. Pewnego rodzaju przeciwwagą dla tych badań może być z kolei oddolny projekt „Archiwum społeczne Głogoczowa na start!”28 oraz poprzedzający go projekt „Nasz Senior - Nasz Skarb”29, realizowane przez Stowarzyszenie Gospodyń Wiejskich w Głogoczowie we współpracy z Wiejskim Domem Kultury w Głogoczowie. Założeniem obu projektów jest to, że wszystkie etapy budowania archiwum wraz z prowadzeniem badań w terenie (wspólne wypracowanie tematyki i kategorii zbiorów, wspólne opracowanie kwestionariuszy ankiet, kart inwentaryzacyjnych itd., wywiady z mieszkańcami prowadzone według koncepcji historii mówionych, identyfikacja lokalnych zasobów dziedzictwa, inwentaryzacja tychże zasobów oraz ich opracowanie, archiwizacja i digitalizacja) realizują sami mieszkańcy (reprezentujący różne grupy). To osoby, które odpowiedziały na apel pomysłodawcy i inicjatora projektu - lokalnego KGW i które przed realizacją przejdą cykl szkoleń przygotowujących je do całego procesu. Jak zostało ujęte we wniosku projektu, mieszkańcy Głogoczowa stają się badaczami, archiwistami i kustoszami własnego dziedzictwa. W projekcie tym pełnię rolę opiekuna merytorycznego - facylitatora - i jednego ze szkoleniowców.

\section{Konkluzje}

Krytyczne, partycypacyjne i mediacyjne badania, a szerzej studia, nad dziedzictwem niematerialnym w działaniu mogą dostarczać społeczeństwu, a dokładniej konkretnym społecznościom, pewne narzędzia do rozwijania - co ważne bezpośrednio przez nie same - różnorodnych działań na rzecz poszczególnych praktyk dziedzictwa niematerialnego, z którymi

${ }^{28}$ Projekt dofinansowany z programu Myślenickie Inicjatywy Lokalne 2020 r. Myślenickiego Ośrodka Kultury i Sportu w Myślenicach.

${ }^{29}$ Projekt dofinansowany z programu „Działaj Lokalnie” Polsko-Amerykańskiej Fundacji Wolności realizowanego przez Akademię Rozwoju Filantropii w Polsce (ARFP) oraz Sieć Ośrodków Działaj Lokalnie. Operatorem dla projektów realizowanych w powiecie myślenickim (w którym znajduje się Głogoczów) jest Fundacja ARTS. 
się utożsamiają. Jednocześnie „narzędzia” te mogą przyczyniać się do aktywizacji pozostałych członków tychże społeczności i wypracowywania w nich otwartych, partycypacyjnych i odpowiedzialnych postaw wobec własnego dziedzictwa. Co więcej, w dalszej perspektywie mogą pomagać przełamywać dominujące dyskursy dziedzictwa niematerialnego występujące tak w obrębie samej społeczności depozytariuszy, jak i szerzej, w wymiarze regionalnym, krajowym czy wreszcie międzynarodowym. W konsekwencji heterodoksyjne i interpretacyjne podejście do dziedzictwa połączone $\mathrm{z}$ brokerstwem kulturowym (rozumianym jako działania mediacyjno-facylitacyjne) oraz z partycypacyjnymi badaniami w działaniu mogą przyczynić się do przełamania pasywnej pozycji depozytariuszy odpowiednio w krajowym i światowym systemie ochrony dziedzictwa niematerialnego.

Obecnie - jak zostało zasygnalizowane we wprowadzeniu - ich rola daleka jest od faktycznej decyzyjności i sprawczości. Zaproponowana przeze mnie perspektywa metodologiczna oparta na teorii heterodoksyjnej czyni depozytariuszy oficjalnie równoprawnymi partnerami i przede wszystkim kluczowymi graczami, którzy sami mogą (pomijając, że de facto od zawsze w różnym stopniu i zakresie to robili) zarówno zachowywać, chronić, rozwijać, jak i badać swoje dziedzictwo - nie zaś jedynie pełnić rolę tych, którym trzeba w tym pomóc, m.in. pokazując gotowe rozwiązania i dyrektywy, które muszą w tym celu wdrożyć. Taki układ automatycznie zmienia pozycję uprzywilejowanych dotychczas ekspertów. Z roli strażników, reżyserów i arbitrów - jak w dużej mierze nadal postrzegana jest dziś społeczna funkcja etnografa, antropologa dziedzictwa, muzealnika-kustosza, archiwisty, inwentaryzatora czy konserwatora rozstrzygającego, co i jak zachowywać i chronić, stają się oni tzw. pomocnikami-przewodnikami z wiedzą i zasobem źródłowym, które są depozytariuszom niezbędne $\mathrm{w}$ zmaganiu się $\mathrm{z}$ własnym dziedzictwem $\mathrm{i}$ jego różnorodnymi reprezentacjami. Stają się bardziej doradcami i konsultantami. Tym samym nie są już oni jedynymi interpretatorami i ,tłumaczami" danych praktyk dziedzictwa zarówno w wymiarze historycznym, jak i współczesnym. Być może dlatego przedstawiciele krytycznych studiów nad dziedzictwem podkreślają, że rola ekspertów w przypadku dziedzictwa się skończyła lub że wręcz wszyscy jesteśmy dziś ekspertami dziedzictwa (uściślijmy - swojego własnego dziedzictwa). Czym innym jest przy tym rola mediatorów i facylitatorów oraz tzw. zawodowych współbadaczy w działaniu. 
Badanie dziedzictwa niematerialnego w działaniu...

Krytyczne badania dziedzictwa tyczą się zatem nie tylko świadomości ich uwikłania terenowego, ale również bezpośrednio autorefleksyjnego podejścia do pozaakademickiej roli badacza-działacza nie tylko w popularnych dziś projektach animacyjnych i tych z zakresu edukacji kulturowej i międzykulturowej (w tym regionalnej), ale także w szeroko rozumianych przeglądach, konkursach, festiwalach folklorystycznych oraz folkowych i etnicznych, targach, kiermaszach i jarmarkach szeroko pojętej sztuki ludowej, rękodzieła i rzemieślnictwa, komisjach artystyczno-etnograficznych, komisjach dziedzictwa kulinarnego (np. regionalne i krajowe listy produktów tradycyjnych, lokalne, regionalne i ogólnokrajowe konkursy na potrawy tradycyjne), radach muzealnych oraz innych instytucjach i organizacjach (np. tych decydujących o podziale środków lub przyznających tematyczne nagrody), ze stosunkowo młodą (powołana w 2013 roku) Radą ds. Niematerialnego Dziedzictwa Kulturowego działającą przy Ministrze Kultury i Dziedzictwa Narodowego włącznie. Zmiana ta mogłaby się przyczynić do przełamania stereotypu etnografa w mediach, w instytucjach kultury, muzeach, ruchu folklorystycznym itd. Jak twierdzi Jackobs, gdy idzie o dziedzictwo w sferze publicznej, wszyscy ${ }^{30}$ wypadają lepiej od antropologów (Jackobs 2014: 267).

Jednocześnie partycypacyjne badania dziedzictwa $\mathrm{w}$ działaniu nie powinny być rozumiane jako opozycyjna alternatywa tzw. klasycznych etnograficznych badań terenowych, a jedynie jako jedna z ich metod czy, szerzej, jeden z rodzajów współczesnych badań antropologicznych w ogóle, niezależnie od tego, czy toczyć się one mają w danych wspólnotach autonomicznie, czy jako uzupełnienie i dopełnienie tych i innych badań.

Tunbridge pisze, że obecnie możemy zaobserwować swoistą zmianę warty w obrębie dziedzictwa. Według niego polega ona na tym, że ,pokolenie pionierów przekazuje pałeczkę ogromnej rzeszy młodych badaczy specjalizujących się w rozmaitych dyscyplinach. To oni stoją dziś przed wyzwaniem bezpiecznego przeprowadzenia badań nad dziedzictwem przez nawałnice, jakie pojawią się w przyszłości” (Tunbridge 2018: 287). W przypadku heterodoksyjnych, partycypacyjnych i mediacyjnych podejść do dziedzictwa w działaniu wspomniana zmiana warty polegałaby dodatkowo na podzieleniu się ową odpowiedzialnością za badania dziedzictwa oraz za różnorodne działania prowadzone w jego obrębie z tzw. zwykłymi obywatelami, członkami danych społeczności i grup, a dokład-

${ }^{30}$ Wymienia tu m.in. prawników, marketingowców, menadżerów, artystów, dyplomatów, urzędników, animatorów, edukatorów, społeczników. 
niej rzecz ujmując - na uznaniu i docenieniu ich oddolnej działalności, nie zawsze funkcjonującej jako oficjalna czy też usankcjonowana, którą wykonują już od dawna, oraz na wejściu z nimi w regularną, a przede wszystkim równoprawną, współpracę. Przecież koniec końców wszyscy jesteśmy depozytariuszami jakiegoś dziedzictwa, a dokładniej różnych dziedzictw, niezależnie od tego, czy podchodzimy do nich z pozycji teoretyka czy praktyka, oraz w sposób czynnościowy, nominatywny czy deklaratywny.

\section{BIBLIOGRAFIA:}

Ashworth, G.J. (2016). The heritage crusade. Have we won or lost? Tekst niepublikowany.

AlAnood Bin, A. (2017). The Value of Authenticity in Heritagization: An Exploratory Case-study on Dubai Historical District. Dubai.

Austin, J.L. (1962). How to Do Things with Words. Oxford: Oxford University Press.

Austin, J.L. (1993). Mówienie i poznawanie. Rozprawy i wykłady filozoficzne (tłum. B. Chwedeńczuk). Warszawa: Wydawnictwo Naukowe PWN.

Bauman, Z. (2012). Kultura jako praxis (thum. J. Konieczny). Warszawa.

Bendix, R. (2009). Heritage between economy and politics: an assessment from the perspective of cultural anthropology. W: L. Smith, N. Akagawa (red.), Intangible Heritage. London.

Bernbeck, R. (2013). Heritage Void and the Void as Heritage. Archaeologies, 9(3), 526-545.

Bujdosóa, Z., Dávidb, L., Tőzsérc, A., Kovácsd, G. i in. (2015). Basis of Heritagization and Cultural Tourism Development. Procedia-Social and Behavioral Sciences, 188, 307-315.

Byrne, D. (1991). Western hegemony in archaeological heritage management. History and Anthropology, 5, 269-276.

Cervinkova, H. (2011). Edukacyjne badania w działaniu - w poszukiwaniu emancypacyjnego wymiaru badań pedagogicznych i antropologicznych. W: Badania w działaniu - nowy paradygmat, Animacja Życia Publicznego, Zeszyty Centrum Badań Społeczności i Polityk Lokalnych, 2(5), 7-11.

Chrostowski, A., Jemielniak, D. (2011). Skuteczne doradztwo strategiczne: metoda Action Research w praktyce. Warszawa: Poltext. 
Badanie dziedzictwa niematerialnego w działaniu...

Daly, P., Chan, B. (2015). "Putting broken pieces back together": Reconciliation, justice, and heritage in post-conflict situations. W: W. Logan, M.N. Craith, U. Kocke (red.), A companion to heritage studies (s. 491-506). Malden, MA: John Wiley and Sons.

Definicja. W: Archiwa Społeczne. Pozyskano z https://archiwa.org/definicja.

Dudek, K., Sikora, S. (2016). Wytwarzanie dziedzictwa. Z Barbarą Kirshenblatt-Gimblett rozmawiają Karolina J. Dudek i Sławomir Sikora. Muzealnictwo, $57,33-41$.

Dudkiewicz, M. (2011). Metodologiczny kontekst badań aktywizujących. W: Animacja Życia Publicznego. Zeszyty Centrum Badań Społeczności i Polityk Lokalnych, 2(5), 4-7.

Dudzik, W. (2009). Posłowie do wydania polskiego. W: J.J. MacAloon (red.), Rytuat, dramat, święto, spektakl. Wstęp do teorii widowiska kulturowego (tłum. K. Przyłuska-Urbanowicz) (s. 421-428). Warszawa.

Dziadowiec, J. (2012). Międzynarodowe festiwale folklorystyczne i folkowe spotkania kultur jako współczesne formy spektaklizacji i ludyzacji folkloru oraz kultury tradycyjnej. W: K. Skowronek, K. Leszczyńska (red.), Performatywne wymiary kultury (s. 141-157). Kraków: Wydawnictwo Libron.

Dziadowiec, J. (2014). Interkulturowe festum folkloricum jako konstrukt i metakomentarz społeczno-kulturowy. Prace Etnograficzne, 42, 2, 135-145.

Dziadowiec, J. (2016). Festum folkloricum. Performatywność folkloru w kulturze wspołczesnej. Rzecz o międzykulturowych festiwalach folklorystycznych. Warszawa: Narodowe Centrum Kultury.

Dziadowiec, J. (2016). Imprezy folklorystyczne jako forma folkturystyki/etnoturystyki oraz forma organizacji i zarządzania dziedzictwem niematerialnym. Perspektywa folkorganizatorów i folkturystów. Relacje między turystyka, kultura a dziedzictwem, Turystyka kulturowa, 3/2016, 91-115.

Dziadowiec, J. (2016). Interkulturowe festiwale folklorystyczne jako metawidowiska - obraz z perspektywy uczestniczącej. W: E. Wilk, A. Nacher, M. Zdrodowska, E. Twardoch, M. Gulik (red.), Więcej niż obraz. Przestrzenie wizualne, t. 2 (s. 145-162). Gdańsk: Wydawnictwo Naukowe Katedra.

Dziadowiec, J. (2017). The Jagiellonian Ideas in the Promotion of Intangible Cultural Heritage. On the Example of Polish Jagiellonian Fairs. W: L. Korporowicz, S. Jaskuła, M. Stefanovič, P. Plichta (red.), Jagiellonian Ideas - Towards Challenges of the Present Time (s. 379-407). Kraków: Wydawnictwo Biblioteka Jagiellońska. 
Dziadowiec-Greganić, J. (2019). Studia festiwalowe i ruch folklorystyczny $\mathrm{w}$ Polsce $\mathrm{w}$ kontekście polityki UNESCO w zakresie niematerialnego dziedzictwa kulturowego - pomiędzy modelem programowym ready made a performatywnym modelem turkusowym. W: A.W. Brzezińska, K. Smyk (red.), Festiwale, konkursy, przeglady a ochrona niematerialnego dziedzictwa kulturowego, t. 4 serii „Niematerialne dziedzictwo kulturowe w Polsce i jego ochrona" (s. 57-77). Lublin - Wrocław - Warszawa: Wydawnictwo UMCS, Polskie Towarzystwo Ludoznawcze, Narodowy Instytut Dziedzictwa.

Dziadowiec-Greganić, J., Dudek, A. (2019). Handmade in Wiśniowa. O najbardziej materialnym z niematerialnych aspektów dziedzictwa kulturowego w pogranicznej gminie Wiśniowa. Seria „Archiwum Etnograficzne” 63. Wrocław - Wiśniowa: Polskie Towarzystwo Ludoznawcze, Gminny Ośrodek Kultury i Sportu w Wiśniowej.

Emerick, K. (2014). Conserving and managing ancient monuments: Heritage, democracy, and inclusion. Woodbridge: Boydell \& Brewer.

European Commission launches Cultural Heritage In Action programme. (2020). W: European Commission. Pozyskano z https:/ec.europa.eu/culture/news/ european-commission-launches-cultural-heritage-in-action-programme_en.

Gmurzyńska, E. (2009). Rodzaje mediacji. W: E. Gmurzyńska, R. Morek (red.), Mediacje. Teoria i praktyka (s. 111-120). Warszawa: Wydawnictwo Wolters Kluwer.

Hall, S. (1999). Whose Heritage? Unsettling „The Heritage”, Reimagining the postnation. Third Text, 13(49), 3-13.

Harrison, R. (2010). Heritage as social action. W: S. West (red.), Understanding heritage in practice (240-276). Manchester: University Press.

Harrison, R. (2010). Introduction. W: R. Harrison (red.), Understanding the politics of heritage (s. 5-42). Manchester: Manchester University Press.

Harrison, R. (2013). Heritage: Critical Approaches. Oxon\&New York: Routledge.

Hobsbawm, E., Ranger, T. (red.) (2008). Tradycja wynaleziona (tłum. M. Godyń, F. Godyń). Kraków.

Hymes, D. (1975). Breakthrough into Performance. W: D. Ben-Amos, K. S. Goldstwin (red.), Folklore: Performance and Communication. The Hague.

Jacobs, M., Neyrinck, J., van der Zeijden, A. (2014). UNESCO, Brokers and Critical Success (F)Actors in Safeguarding Intangible Cultural Heritage. Volkskunde. Tijdschrift over de cultuur van het dagelijks leven, 115, 3, 249-256.

Jünger, E. (2009). Tradycja. Husaria Tradycji, 3, 8-11.

Kirshenblatt-Gimblett, B. (1998). Destination Culture: Tourism, Museums and Heritage. Berkeley. 
Badanie dziedzictwa niematerialnego w działaniu...

Klekot, E. (2015). Ikony zografskie i klasztory Fruškiej Gory a serbskie imaginarium narodowe. Lud, 99, 139-159.

Klekot, E. (2016). Dziedzictwo i jego antropologia. Rocznik Antropologii Historii, $\operatorname{VI}(9), 7-13$.

Kolankiewicz, L. (2005). Wstęp: ku antropologii widowisk. W: A. Chałupnik, W. Dudzik, M. Kanabrodzki, L. Kolankiewicz (oprac.), Antropologia widowisk. Zagadnienia i wybór tekstów (s. 9-31). Warszawa.

Konwencja UNESCO z 1972 roku w sprawie ochrony światowego dziedzictwa kulturowego i naturalnego. Pozyskano z http://www.unesco.pl/fileadmin/ user_upload/pdf/Konwencja_o_ochronie_swiatowego_dziedzictwa.pdf.

Konwencja UNESCO z 2003 roku w sprawie ochrony niematerialnego dziedzictwa kulturowego. Pozyskano z http://www.unesco.pl/fileadmin/user_upload/pdf/Konwencja_o_ochronie_dz._niemater_2003.pdf.

Kopaliński, W. (red.) (1970). Słownik wyrazów obcych i zwrotów obcojęzycznych. Warszawa: Wiedza Powszechna.

Kowalski, K. (2013). O istocie dziedzictwa europejskiego - rozważania. Kraków: Międzynarodowe Centrum Kultury.

Lewin, K. (1946). Action research and minority problems. J Soc. Issues 2(4), 34-46.

Logan, W., Wijesuriya, G. (2015). The new heritage studies and education, training, and capacity-building. W: W. Logan, M.N. Craith, U. Kocke (red.), A companion to heritage studies (s. 557-573). Malden, MA: John Wiley and Sons.

Lowenthal, D. (1985). The past is a foreign country. Cambridge.

Łuniewska, L. (2008). Santa Claus przynosi dynie. Wywiad z Waldemarem Kuligowskim. Newsweek, 1, 93-95.

MacAloon, J.J. (2009). Wstęp: widowiska kulturowe, teoria kultury. W: J.J. MacAloon (red.), Rytuat, dramat, święto, spektakl. Wstęp do teorii widowiska kulturowego (tłum. K. Przyłuska-Urbanowicz). Warszawa.

Mann, T., Marszewska, J. (2018). Facylitacja - wiedza, umiejętności, sztuka czy magia. Warszawa: Wydawnictwo RP.

Mosse, D., Lewis, D. (red.) (2006). Development Brokers and Translators: The Ethnography of Aid and Agencies. Kumarian Press.

Nahodil, O. (1991). Tradycja jako definiens kultury. Lud, 74, 5-21.

Otwarty System Archiwizacji (OSA). Pozyskano z https://osa.archiwa.org/.

Pomian, K. (2010). Narodziny i przemiany dziedzictwa europejskiego. W: N. Dołowy-Rybińska, A. Gronowska, A. Karpowicz, I. Piotrowski, P. Rodak (red.), Sploty kultury. Ksiega ku czci prof. Andrzeja Mencwela (s. 38-46). Warszawa. 
Reckwitz, A. (2002). Practices and Their Affects. W: A. Hui, T. Schatzki, E. Shove (red.), The Nexus of Practice: Connections, Constellations and Practitioners (s. 115-125). Abingdon: Routledge.

Reckwitz, A. (2002). Toward a Theory of Social Practices: A Development in Culturalist Theorizing. European Journal of Social Theory, 5, 243-263.

Robertson, I.J.M. (2008). Heritage from below: class, social protest and resistance. W: P. Graham, P. Howard (red.) The Ashgate Research Companion to Heritage and Identity, Aldershot (s. 143-158). Ashgate.

Rusek, R. (2018). John Tunbridge - heritolog przełomu wieków. W: J.E. Tunbridge, Zmiana warty. Dziedzictwo na przełomie XX i XXI wieku (thum. A. Kamińska) (s. 5-9). Kraków: Międzynarodowe Centrum Kultury.

Schatzki, T. (1996). Social Practices. A Wittgensteinian Approach to Human Activity and the Social. Cambridge.

Schatzki, T. (2001). Introduction: Practice Theory. W: T. Schatzki, K. Knorr Cetina, E. von Savigny (red.), The Practice Turn in Contemporary Theory (s. 10-23). London.

Schatzki, T. (2012). A Primer on Practices: Theory and Research. W: J. Higgs, R. Barnett, S. Billett, M. Hutchings, F. Trede (red.), Practice-Based Education. Perspectives and Strategies (s. 13-26). Rotterdam.

Schechner, R. (1988). Performance Theory. New York.

Schechner, R. (2002). Performance Studies: An Introduction. New York.

Schechner, R. (2006). Performatyka: Wstepp. (tłum. T. Kubikowski). Wrocław.

Sennett, R. (2008). The Craftsman. London: New Haven.

Silverman, H., Waterton, E., Watson S., (2017). An introduction to heritage in action. W: H. Silverman, E. Waterton, S. Watson (red.), Heritage in Action: Making the Past in the Present (s. 3-18). Cham: Springer.

Singer, M. (1959). Traditional India: Structure and Change. Philadelphia.

Smith, L. (2006). Uses of Heritage. Abingdon and New York: Routledge.

Smith, L. (2013). The Intangible Cultural Heritage Convention, a Challenge to the Authorised Heritage Discourse? W: Evaluating the Inscription Criteria for the Two Lists of UNESCO's Intangible Cultural Heritage Convention. The 10th Anniversary of the 2003 Convention. Final Report (s. 122-128). Osaka: International Research Centre for Intangible Cultural Heritage in the Asia-Pacific Region.

Smith, L. (2016). „Zwierciadło dziedzictwa”: narcystyczna iluzja czy zwielokrotnione odbicie. Rocznik Antropologii Historii, VI(9), 25-44.

Smith, L., Shackel, P., Campbell, G. (2011). Introduction: Class still matters. W: L. Smith, P. Shackel, G. Campbell (red.), Heritage, Labour and the Working Classes (s. 1-16). London: Routledge. 
Szacki, J. (1971). Tradycja. Przegląd problematyki. Warszawa.

Traditional Craftsmanship. Pozyskano z https://ich.unesco.org/en/traditionalcraftsmanship-00057.

Tunbridge, J.E. (2018). Zmiana warty. Dziedzictwo na przełomie XX i XXI wieku (tłum. A. Kamińska). Kraków: Międzynarodowe Centrum Kultury.

Tunbridge, J.E. Ashworth, G.J. (1996). Dissonant heritage. The management of the past as a resource in conflict. Chichester.

Twelvetrees, A.C. (2014). Pracując ze społecznościa (tłum. Anna Konieczna-Purchała). Warszawa: Instytut Spraw Publicznych.

Waterton, E. (2009). Sites of sights: Picturing heritage, power and exclusion, Journal of Heritage Tourism, 4(1), 37-56.

Wells, J. (2017). What is Critical Heritage Studies and how does it incorporate the discipline of history? Conserving the Human Environment. Balancing Practice between Meanings and Fabric. Pozyskano z https://heritagestudies. org/index.php/2017/06/28/what-is-critical-heritage-studies-and-how-doesit-incorporate-the-discipline-of-history/.

West, S., Bowman, M. (2010). Heritage as performance. W: S. West (red.), Understanding heritage in practice (s. 277-305). Manchester: University Press.

Winter, T. (2013). Clarifying the critical in critical heritage studies. International Journal of Heritage Studies, 19, 6, 532-545.

Wiśniowski Jarmark Rzemiost i Zawodów Tradycyjnych - lokalna tradycja $w$ działaniu. Pozyskano z http://wisniowskijarmark.gokis-wisniowa.pl/.

Zawiła, M. (2019). Dziedziczynienie przedwojennych cmentarzy na terenach postmigracyjnych Polski. Kraków.

Małopolska Źródłem Tradycji. Pozyskano z http://mcksokol.pl/malopolska-zrodlem-tradycji 